УДК 316.77.001

\title{
THE REQUIREMENTS OF SOCIETY: THE IMPERATIVE FOR JOURNALISM AND PUBLIC RELATIONS
}

\author{
L.N. Fedotova \\ Peoples' Friendship University of Russia \\ 10/2, Miklukho-Maklaya str., Moscow, 117198, Russian Federation
}

\begin{abstract}
The article examines the conceptual framework that describes the interaction of public relations and journalism with society at large by using the terms "corporate social responsibility" and "social mission". Public attention to this problem is inseparable from the increased importance in the public opinion of the place and role of business in the life of society and the responsibilities of business. In parallel to this process there was an increasing demand for adequate information support of business processes, in particular, for public relations - its place and role, as well as for journalism, as a mirror of the main events, processes, activities of political and economic actors.
\end{abstract}

Key words: investigative journalism, the "muckrakers", public relations, codes of ethics, corporate social responsibility, social mission

The article examines the conceptual framework that describes the interaction of society in general and such professional and social activities as public relations and journalism by using the "corporate social responsibility" (CSR) and "social mission" notions. We would like to emphasize that this is a historically emerging situation that depends on many parameters of social development, primarily on the economic and political structure.

In 1956, Wilbur Schramm, an American sociologist, and his colleagues, summarizing the development of the Western press for a long period, introduced the notion of "social responsibility" [1]. They had analyzed a long period of development of the world press, putting forward not so many characteristics as types of attributes: relations with the government and the state; who has the right to use the media; what are the levers of control over the press; who can or should not criticize the political machine and the officials who serve it: what is the property of the press institutes; features of the audience; the rights of information canals and their capabilities (media rights and uses).

Typology of the press is built on the characteristics that are essential for the practice of the functioning of the press in different countries. For these reasons, this model logically replaces the authoritarian and libertarian model, opposed to the Soviet totalitarian model. Indeed, the types of attributes proposed as mutually exclusive are mutually exclusive in different systems, although, as always, the devil shows himself in detail. And we will notice, the change of these models is only logical - in the historical context, for example, today, on the world press map we will find all of this the models existing equitably...

And it was the grounds suggested by the authors that a special model was singled out (I prefer this word instead of the theory) to the relationship between the characteristics 
they singled out - the Social Responsibility Theory. According to the authors, this theory corresponds to the practice of the functioning of the press in the United States in the twentieth century. They postulate that philosophical and sociological grounds go back to the practice of the Freedom of the Press Commission of the late $18^{\text {th }}$ century, as well as to the ethical codes of the mass media adopted at that time. In theory and practice, the main goal is declared: to inform, entertain and sell by placing advertising, but basically to transfer the conflict on the level of discussion. The right to use the media has everyone who has something to say. The levers of control over the press - public opinion, consumer actions, professional ethics. Serious interference in the sphere of individual rights and vital public interests is prohibited. There are primarily private property, or state, when the government provides public interests. A distinctive feature is that the media should become socially responsible, otherwise society has to force them to be so.

So, in the scientific discourse the phrase "social responsibility" was thrown in, although, for example, professional codes, and there were a lot of them in the United States, were treated simply as "responsibility". For example, in the Code of Ethics of the Society of Professional Journalists of the United States, the article "Responsibility" is not very verbose: Ensuring the right of citizens to know about important and interesting events for society is the dominant task of the media. Service welfare of society is the purpose of disseminating news and a balanced comment. Journalists who use their professional status of representatives of society for mercenary or other unworthy purposes, abuse its high confidence. True, there are other fairly detailed articles in the Code of Ethics: Freedom of the Press, Ethics, Accuracy and Objectivity, Conscientious Attitude to Labor, and Mutual Trust.

In the Declaration of Principles of the American Society of Newspaper Editors "Associated Press, AP" (AP Managing Editors' Code of Ethics for Newspapers) 1975, we read in the article "Responsibility": The main purpose of gathering and disseminating news and opinions is to serve the universal benefit by informing people and giving them the opportunity to form judgments on topical issues. Employees of newspapers which abuse their professional status in selfish interests or with unworthy goals, disregard the public's trust. The American press became free not only to inform people or provide them with a discussion rostrum, but also to independently supervise the governing structures of society, including the behavior of government agencies at all levels. And again - in addition - the articles "Freedom of the press", "Independence", "Truth and accuracy", "Impartiality", "Decency". And in addition the articles "Freedom of the press", "Independence", "Truth and accuracy", "Impartiality", "Decency".

What kind of Americans! They would have rewrote the Bible here!

The variant of the Code of Ethics for newspapers and their employees, adopted by the chief editors of the Associated Press Agency on April 15, 1975, is even more verbose. The article "Responsibility" already consists of four paragraphs: A good newspaper can be called, which is fair, accurate, honest, responsible and decent. Its guiding principle is truth. She avoids being involved in matters that may conflict with her ability to report and interpret news honestly and unbiassedly. The newspaper must be a constructive critic of all strata of society. It must energetically disclose misconduct and abuse of power structures, in the public and private sectors as well. In editorial policy, it must act in favor of reforms and progress in the interests of society ... The newspaper must refute by the 
facts those statements of political figures, which, to the best of its knowledge, do not correspond to the truth or mislead people. It should support freedom of speech and freedom of the press, as well as respect the human right to non-interference in his personal life. Also, the priority is the right of citizens to know the truth about important issues; the newspaper must vigorously strive for public access to information on the activities of state bodies by ensuring the practice of public meetings and open archives. Plus articles "Precision", "Integrity", "Conflict of interest".

So, after the work of the three authors on the theory of social responsibility in the science of mass media, a systematic and detailed discussion was begun with the notion of "responsibility" in this structure. Thus, the first studies of this kind are considered by the researchers themselves as these are the publications of J.R. Pennock (1960), L. Freund (1960), H.R. Niebuhr (1963) and E.L. Pincoffs (1975) [2].

The very set of requirements for the press may have different generalizations or do without them at all. So, for example, in 1997 at the conference at the Faculty of Journalism of Moscow State University (Oct., 23-25) a well-known researcher of mass information processes K. Nordenstr g delivered a speech. His report was based on a study conducted by sociologists with 30 codes of professional ethics for European journalists as an object of study. The main idea of these codes is the protection of the rights of the public, citizens, the focus of attention on the democratic aspect of the existence of media in society.

The most frequent clauses in the codes are truthfulness, freedom of speech, equality in embracing different political forces, justice, reliability of information sources... Noting the existence of different approaches to the problem in different cultural and social entities, the speaker declared the need for shared values such as human dignity, truthfulness, the value of humanism and human life, the value of individualism. Or in November 2012 at the Faculty of Journalism of Moscow State University in the framework of the "Fourth International Readings on the problems of mass communications" in a number of speeches, such positions sounded: parts of journalism culture are remoteness from power; the audience is seen more as citizens, and only then as consumers; objectivism Gregory Simons (Sweden), talking about constituents of journalism, gave them such empirical content: truth, loyalty to citizens, fact checking, a forum for discussing social problems. If desired, this can be called a social mission.

In the very abundance of concepts describing some empirically observed phenomenon, in our time there is nothing reprehensible. On this account I will give the reflections of the famous French sociologist and culturologist A. Mole, who gives a methodological explanation for the synonymic conceptual series in science: "The scholastic and humanistic tradition, having an example of geometry before its eyes, saw in the search for determinants an indispensable prerequisite for all knowledge. Modern thinking in this sense is much more liberal: today it no longer seems absolutely necessary to determine in advance all the words used to build legitimate statements of these words. The definitions by which the pragmatist is ready to settle are examples of "situational comprehension" of a definable word. Such definitions do not pretend to be exhaustive completeness and often boil down to a sequence of exact - that is, logically consistent - statements. The word in question in this case acts as a "summary" of the totality of these utterances" [3].

So, the theory of mass communications gave to the whole sphere of information activity the notion of "social responsibility". 
It is clear that such a theory was fueled by the practice of journalism. In this connection, I would like to draw attention to the peculiar point of intersection of journalism and such professional activity as public relations, where both the concepts of social responsibility and social mission have entered into fullness.

These mutual influences are extremely interesting to analyze.

Some deepening in the history of Public Relations shows that with this name, this professional activity has already actualized special relations with the "public" (read: with the society). The public here has designated as a significant, valuable, important, which at least implies mutually interested relations of counterparties.

In the early twentieth century. in the USA, the homeland of public relations, events took place that are important for understanding transformations both in this sphere and in the field of journalism. We must remember the period in American journalism, which retained the name of "muckrakers" [4]. The movement of "muckrakers" has witnessed a new stage in the development not only of American journalism, but also of the level of public consciousness. In the country there was a strong socialist and trade union movement, feminist groups, and public organizations that advocated respect for the rights of various social groups and demanded profound social transformations.

At the beginning of the century an event took place in the United States, which had symbolic significance. In 1901, "United States Steel Trust" became the first American firm with a capital of more than $\$ 1$ billion. According to American progressivists of the beginning of the century, such economic power was a threat to the public good. In the hands of the government there were no legislative tools that could effectively influence the monsters of big business.

However, in this situation, we are interested in journalism.

For these same years, the peak of the popularity of inexpensive magazines has occurred. They were possible to publish more deeper materials than the daily newspapers, and the weekly periodicity allowed journal publications to remain relevant, topical.

The first revealing stories in the popular magazine "McClure's Magazine" by a journalist A. Tarbell were devoted to the investigation of the activities of the J. Rockefeller's trust "Standard Oil". In January 1903, "McClure's" published the first of 18 materials of A. Tarbell, as well as with two other journalistic investigations. They were preceded by the following introduction: "All these materials can be entitled "American contempt for the law". Capitalists, workers, politicians, other citizens - they all violate the law or allow it to transgress. Is there anyone who will protect him? Nobody except us" [5].

Tarbell A. for four years, collected information and published materials about the "Standard Oil". The basis of her journalistic investigation was the judicial archives and published data of the US Congressional proceedings on the activities of the trusts. In her eighteen articles, she described in detail the illegal and unscrupulous methods that Standard Oil did not disdain in order to ruin its competitors. The journalist has documented the active work of the Public Relations Department of Standard Oil, which established friendly relations with 110 newspapers in Ohio, who now and then published extremely positive materials about the company (sic!).

Publications of the McClures magazine prompted the government to launch a largescale investigation of Standard Oil's activities, which ended in 1911 with an antitrust Supreme Court ruling, according to which the corporation was divided into several 
companies. Rockefeller had to make a lot of efforts by using the entire arsenal of his public relations agencies to somehow restore his reputation.

Soon, the U. Hurst's magazine "Cosmopolitan" picked up the torch of revelations. A series of articles entitled "Betrayal of the Senate" caused a wide public response, culminating in the famous speech of President Theodore Roosevelt, where he introduced this notion of "muckrakers". The author named the numbers of senators representing the interests of certain business circles. As a result, some state men have paid with their posts.

The author of the article, A.K. Malakhovsky, gives examples that even such a public institution, as untouchable as before, like the church, fell under the fire of criticism of "muckrakers". The New York magazine "Everybody's" published a sensational revelation in 1908: the New York Trinity Church, known for its charity, found money to help the poor from their income from the surrender in the hiring of houses, which were almost the most horrific slums in New York. Almost all aspects of the life of American society fell under the magnifying glass and scathing criticism. In general, in the period from 1902 to 1915 in the American press, about 2,000 articles of "muckrakers" appeared [6]. US lawmakers adopted a number of laws that put under control the most egregious abuses by the big business.

In 1911 the magazine "Collier's" began to publish a series of articles by U. Irvin "The American Newspaper". Fifteen materials, based on interviews with many journalists and editors, were devoted to exposing the press of W. Hurst. It turned out that both the news notes and editorial comments of the Hirst press were customized, ensuring the interests of advertisers.

Such publications stimulated the movement in favor of increasing the professional requirements of journalists to themselves. Journalists have become more aware of their influence on the public consciousness and understand what burden of responsibility lies with journalists. In the journalistic environment, the requirements to the level of professionalism increased: at universities there were courses designed to train professional journalists. As a result, there were the number of student-journalists who formed the public organization "Sigma-Delta-Chi", which later became a nationwide Society of Professional journalists. In some states, local associations of journalists began to adopt codes of professional ethics. The publicity of politics and of big business, the greater participation of citizens in making government decisions - this is the influence that the movement of "muckrakers" had on the public life of the country. The conclusion of the author of the article is important: it was after high-profile revelations of "muckrakers" that large entrepreneurs began to spend considerable sums on PR services.

Nevertheless, gradually, according to the growing, in the climate around the business in the 70-80's XX century critical appraisals began to accrue: business was accused of falling of trust to all other social institutions of the society; environmental problems directly related to business; corruption in business was accentuated.

In many respects, all this was the result of processes that took place in the activities of public relations structures in business: they exaggerated social results of business activities; concealed negative information about their activities although it became known from the press; created the pseudo-news events; sometimes frankly deceived the public 
and the press; refused from independent examination of activities; ignored the social interests, etc.

The problem of loss of confidence by business became aware at the international level as well. At the 33rd World Economic Forum in Davos (Switzerland, 2003), it was put on the agenda: how to improve the world economy and restore confidence in it [my italics. L.F.] [7].

In public relations the direction toward "public affairs" was indicated. Priorities were: increasing participation in social programs; increasing presence in the political process; an explanation of market relations in societies as social value.

It is at this time that programs of action on corporate social responsibility and the actualization of the concept of "social mission" in the activities of public relations structures are emerging. The divide was, as it seems, according to the subject of actualization of these concepts: corporate social responsibility was here a generic concept working generally in business, industry, sphere. If it was the level of an individual enterprise, then as part of a more general structure. The social mission was most often a set of values declared by a separate structure, separate firm with a detailed elaboration of social potencies.

In my opinion, this concept — "social mission" - could appear in Russia only under certain socio-political conditions. It, at least, requires a special position of the link in question - whose social mission? - along with others in a system of interconnected social structures ... We must have in the society a set of social institutions (state, political parties and movements, public opinion, business, society interested in social advertising, public relations structures, the audience, individuals and etc.), which must have an equiprobable and equilibrium (ideally, in a potency) opportunity to actualize their interests, appeal to the society, and be present in public space. They must exist in a competitive, changing field of relations, otherwise it would not make sense to introduce the duty position...

Apparently, in the scientific discourse in our country such a term would be problematic in principle until the 90's of the last century: at a certain period, when the place of each link in the structure of mass media production was strictly predetermined, it was hierarchized, there could be no scientific discussion on this matter. It was logical that we used it only in the era of glasnost and perestroika, and especially now, in our days, that a certain kind of inclination towards the dominance of power structures (or businesses, etc...) has become noticeable ... There was a need to actualize a full participant in these processes: society as a whole, or the part that we identify as an audience ... But even in the case of the existence of a ramified system of legislative regulations and professional codes on this account, the public and scientific reflection as well on this or that occasion - the phenomenon is normal.

Let's take an example of the attitude of the Russian business community to the problem of corporate social responsibility. We can say that it is now at the peak of interest. In 2006, the Association of Managers of Russia presented a memorandum "On the principles of corporate social responsibility (CSR)". The main principles: the production of quality products and services, the creation of attractive jobs, the implementation of legal requirements, taking into account public expectations and generally accepted ethical norms in the practice of conducting business, building bona fide and mutually beneficial relations with all stakeholders. There should be a place for partnership with the state and 
society in the implementation of social programs. It was emphasized that the principles of CSR in Russia should not depart from international standards.

Social responsibility of business is increasingly becoming a topic of discussion in the Russian business community. More and more enterprises and organizations come to the conclusion that without a strategy involving participation in solving social and economic problems of society, it is indispensable. Companies strive to fill their relationship with society by the humanitarian meaning. World trends clearly indicate that business reputation will increasingly depend on how socially responsible a citizen is its carrier. In developed countries, the concept of "social responsibility" of business has long become an economic category, which is also taken into account when calculating the level of companies' capitalization.

Should businessmen share their wealth with the people and build on their own money kindergartens, schools and hospitals? In the course of the survey, 1600 respondents in 46 regions of the country answered the question: is it necessary for businesses to participate in social programs or is it solely the state's concern? Surprisingly, according to the survey of the All-Russia Public Opinion Research Center, but $48 \%$ of Russians believe that business in the first place should think about increasing economic efficiency of his firm or enterprise, and only then about schools and hospitals. And the state will take care of the welfare of the people; $44 \%$ of respondents expressed their opinion on social responsibility of business [8].

The editorial board of Sovetnik magazine and Sovetnik.ru Portal together with Subscribe.ru conducted in 2006 a study "Social responsibility of companies whose activities are ambiguously assessed by the society". Interviewed users of the portal. The goal is to find out with what advantages and disadvantages, in their opinion, the implementation of corporate social responsibility is connected. According to the respondents, corporate social responsibility is, most often, "interaction with public organizations, local authorities to solve common social problems" $(50,7 \%)$, "providing a social package to employees" $(45,1 \%)$ and "ethical behavior in relation to consumers, partners, suppliers" $(41,8 \%)$. More rarely, they refer to "participation in philanthropic, philanthropic projects" $(32,9 \%)$, "production of quality goods and services" $(32,4 \%)$, "openness and transparency of business" (28,6\%), "assistance to development of personal potential of workers" $(22,1 \%)$, “environmental activities" $(20,7 \%)$, as well as $(5,2 \%)$ "dialogue with consumers", "pension programs for employees", "responsibility to investors, shareholders" and etc. According to the overwhelming majority of respondents, CSR practice in Russia in the next 3-5 years will develop slowly $(81,5 \%)$. The optimistic point of view is that CSR will get mass distribution - only $12,8 \%$ share it. The survey results show that in reality the corporate social responsibility is not used so often.

There is a UN convention urging business to participate in the formation of new relations with society. Most industries use 28 International Standards of Social Partnership, developed by the UN. This social charter has not been ratified by Russia, but private companies in our country are already engaged in developing their principles of social partnership. Glow of negative emotions, addressed to the business in this situation, will force him to act in this way.

On March 12, 2012, the signing of the "Russian Code of Advertising Practice and Marketing Communication" was held. Representatives of more than 20 industrial and 
public organizations signed the text of the code. The goal is the formation of high standards of advertising activity and their adherence by all participants of the advertising process: "the code will become a fundamental document in the formation of an effective system of self-regulation of the advertising industry and an incentive for making necessary selfrestrictions by its participants". Marketing communication, in particular, should not contain information that, directly or indirectly, by ambiguity or exaggeration, can mislead consumers; she should not abuse the trust of the consumer and/or take advantage of his lack of experience and knowledge; the comparative characteristics of goods for presentation in marketing communication should be selected in good faith and be comparable.

So, we will consider that, at least in terms of declarations, the Russian industry has made a big step forward in this regard. Let's hope that the practice will not lag behind these declarations.

Returning to the term "social mission", we will see in these concepts - CSR and social mission - a lot in common. Indeed, the real activity of the structures for public relations, advertising, journalism exists today in the mode of awareness of their rights by different social actors included in the area of activities such structures. And then it is clear that these professional structures will have to declare their obligations to the society, or its segment groups. For example, when it comes to advertising, we can give examples that at a certain stage of developing society both theorists and practitioners suddenly started talking about the "strangled" groups and the obligations of advertisers and advertising producers in front of them. Indeed, the situation where the image of a woman was exploited in advertising primarily as an erotic object, has long been discussed in both art and journalism. The other groups have attracted public attention: concern about their situation in society was to be a topic for reflecting this society (homeless, segregated on racial grounds, low-income groups, etc.).

So we see that historically these two concepts - CSR and social mission - flowing out of one another, entered the professional consciousness in the activities of public relations structures and journalism in such sequence. The former - CSR - exists as a declaration of the foundations of this activity, moral codes; the second-social mission is limited to the obligations of a particular structure. In the latter, one can see a more stringent demand for its activities, but also the demand to orient employees on this course... Recently, the social mission, as a declaration of intent, has long been part of the formal relationship of individual corporations with the outside world. But often this sphere lacks awareness of the problem by the final performer. Hence, cases are quite common when corporate ethics is in conflict with social ethics.

It is clear from this that for the public relations and advertising sector (and journalism as well) the issues of corporate social responsibility should become one of the most important in the recruitment of professional requirements, as well as the necessary part of training students in this specialty. Society itself is interested in this.

At the level of individual information channels (named newspapers, radio stations, TV channels), it is more logical to use the term of the channel's standard, which is explained by the regulation of these channels within the system (the formulations of the main provisions for licensing activities, niche in the information services market, etc.). It seems that the idea of messianism as a requirement for a separate channel, or, God 
forbid, a separate journalist, would reduce the degree of professional requirements for their activities... We already experienced something similar in the 1990s in our journalism.

Then the empirical equivalents of the mission in this activity will be the characteristics of balance, taking into account the interests of different social actors (the state, political parties and movements, public opinion, business, society as a whole, the audience); polyphonic points of view on what is happening in political space as a whole; representation in the information space of various social groups and strata; satisfaction of interests of different sections of the audience, etc. - i.e. distinctive features of different performance standards.

We believe that all of the above should be included in the professional baggage of a journalist, in his professional consciousness.

\section{REFERENCES}

[1] Siebert F.S., T. Peterson and W. Schramm. Four Theories of the Press. Urbana: University of Illinois Press, 1956.

[2] Pennock, J.R. The Problem of Responsibility. In C.J. Friedrich (ed.) Nomos III: Responsibility (P. 3-27). N.Y., 1960; Freund L. Responsibility - Definitions, distinctions, and applications. In C.J. Friedrich (ed.) Nomos III: Responsibility (P. 28-42). N.Y., 1960; Niebuhr H.R. The Responsible Self. N.Y., 1963; Pincoffs E.L. On being Responsible for what one says. Paper presented at the Speech Communication Association convention, Dec. Houston, TX. 1975.

[3] Mole A. Sociodynamics of Culture. M., 1973. P. 35-36. (Mol' A. Sotsiodinamika kul'tury. M., 1973. S. 35-36.)

[4] Malakhovsky A.K. "Muckrakers": an American dream or reality? // Almanac of the Chair of Theory and History of Journalism of the PFUR "Journalism and Society". 2000. № 1. P. 35-45. (Malakhovskiy A.K. "Razgrebateli gryazi”: amerikanskaya mechta ili real'nost'? // Al'manakh kafedry teorii i istorii zhurnalistiki RUDN «Zhurnalistika i obshchestvo». 2000. № 1. S. 35-45.)

[5] Regier C.C. The Era of the Muckrackers. Chapel Hill, N.C., 1932. P. 55.

[6] Tarbell I. All in the Day's Work: An Autobiography. N.Y., 1939. P. 202-53.

[7] Ogneva E. Davos forum summed up // New Izvestiya. 2003. Jan. 29. (Ogneva E. Davosskiy forum podvel itogi // Novye Izvestiya. 2003. Yanv., 29.)

[8] Shishkunova E. The people forgot the oligarchs // Izvestiya. 2006. Oct., 19. S. 9. (Shishkunova E. Narod zabyl oligarkhov // Izvestiya. 2006. Okt., 19. S. 9.)

(с) Федотова Л.Н., 2018

\section{Article history:}

Received: 20 January 2018

Revised: 10 February 2018

Accepted: 20 February 2018

\section{For citation:}

Fedotova L.N. (2018) The requirements of society: the imperative for journalism and public relations. RUDN Journal of Studies in Literature and Journalism, 23 (2), 224-233. DOI 10.22363/2312-9220-2018-23-2-224-233

\section{Bio Note:}

Fedotova Larisa Nikolaevna, Doctor of sociology, professor of Department of Theory and Practice of Journalism, Peoples' Friendship University of Russia. Contacts: e-mail: fedotova117437@ mail.ru 


\title{
ТРЕБОВАНИЯ ОБЩЕСТВА: ИМПЕРАТИВ ДЛЯ ЖУРНАЛИСТИКИ И СВЯЗЕЙ С ОБЩЕСТВЕННОСТЬЮ
}

\author{
Л.Н. Федотова \\ Российский университет дружбы народов \\ Российская Федерация, 117198, Москва, ул. Миклухо-Маклая, 10/2
}

В статье рассматриваются концептуальные рамки, описывающие взаимодействие журналистики, рекламы и связей с общественностью с обществом в целом с использованием понятий «корпоративная социальная ответственность» и «социальная миссия». Внимание общества к этой проблематике неотделимо от возросшей важности в глазах общественности места и роли бизнеса в жизни общества, обязанностей бизнеса, его ответственности. Параллельно этому процессу шло увеличение требовательности к информационному обеспечению бизнеспроцессов, в частности, к связям с общественностью, а также к журналистике, как зеркалу основных событий, процессов, деятельности политических и экономических акторов.

Ключевые слова: журналистика, «разгребатели грязи», этические нормы, корпоративная социальная ответственность, социальная миссия

\section{СПИСОК ЛИТЕРАТУРЫ}

[1] Siebert F.S., T. Peterson and W. Schramm. Four Theories of the Press. Urbana: University of Illinois Press, 1956.

[2] Pennock J.R. The Problem of Responsibility. In C.J. Friedrich (ed.) Nomos III: Responsibility (P. 3-27). N.Y., 1960; Freund L. Responsibility - Definitions, distinctions, and applications. In C.J. Friedrich (ed.) Nomos III: Responsibility (P. 28-42). N.Y., 1960; Niebuhr H.R. The Responsible Self. N.Y., 1963; Pincoffs E.L. On being Responsible for what one says. Paper presented at the Speech Communication Association convention, Dec. Houston, TX. 1975.

[3] Моль А. Социодинамика культуры. М., 1973. С. 35-36.

[4] Малаховский A.K. «Разгребатели грязи»: американская мечта или реальность? // Альманах кафедры теории и истории журналистики РУДН «Журналистика и общество». 2000. № 1. C. $35-45$.

[5] Regier C.C. The Era of the Muckrackers. Chapel Hill, N.C., 1932. P. 55.

[6] Tarbell I. All in the Day's Work: An Autobiography. N. Y., 1939. P. 202-53.

[7] Огнева Е. Давосский форум подвел итоги // Новые Известия. 2003. Янв., 29.

[8] Шишкунова Е. Народ забыл олигархов // Известия. 2006. Окт., 19. С. 9.

\section{История статьи: \\ Дата поступления в редакцию:20 января 2018 \\ Дата принятия к публикации: 20 февраля 2018}

\section{Для цитирования:}

Федотова Л.Н. Требования общества: императив для журналистики и связей с общественностью // Вестник российского университета дружбы народов. Серия: Литературоведение. Журналистика. 2018. T. 23. № 2. 224-233. DOI 10.22363/2312-9220-2018-23-2-224-233

\section{Сведения об авторе:}

Федотова Лариса Николаевна, доктор социологических наук, профессор кафедры теории и истории журналистики Российского университета дружбы народов. Контактная информация: e-mail: fedotova117437@mail.ru 